2012

\title{
Can the President and Congress Establish a Legislative Veto Mechanism for Jointly Drawing Down a Long and Controversial War?
}

Charles Tiefer

University of Baltimore School of Law, ctiefer@ubalt.edu

Follow this and additional works at: http://scholarworks.law.ubalt.edu/all_fac

Part of the Military, War, and Peace Commons, and the President/Executive Department Commons

\section{Recommended Citation}

Can the President and Congress Establish a Legislative Veto Mechanism for Jointly Drawing Down a Long and Controversial War?, 6 J. Nat'l Sec. L. \& Pol'y 131 (2012)

This Article is brought to you for free and open access by the Faculty Scholarship at ScholarWorks@University of Baltimore School of Law. It has been accepted for inclusion in All Faculty Scholarship by an authorized administrator of ScholarWorks@University of Baltimore School of Law. For more information, please contact snolan@ubalt.edu. 


\title{
Can the President and Congress Establish a Legislative Veto Mechanism for Jointly Drawing Down a Long and Controversial War?
}

\author{
Charles Tiefer* \\ INTRODUCTION
}

In the simplest case: Congress declares war, and does not intrude on the President's solo decision about when the troops come home.' However, in our time, long wars, such as in Afghanistan and Iraq, occur with great tension between the two elected branches of government over the pace of a drawdown. Sometimes it may be a hawkish Congress that disagrees with a President reluctant to continue the war at full troop levels. To find a joint way to draw down the American troops in the war zone, they may seek congressional mechanisms to resolve their differences with interactive processes. Then, constitutional issues arise as to whether a congressional mechanism may use a legislative veto - authorization for a drawdown with a reservation of power for a vote by the two Houses of Congress - so as to let the President draw down troop levels while reserving congressional power to stop that draw down.

These issues illuminate war powers in the abstract; the issues also apply concretely to the main war of the 2010s, namely, the long war in Afghanistan. From 2012 on, the President has drawn down troop levels from their peak, matching the public's reluctance to stay at high levels. Yet, elements in the Congress may oppose, at some time, the pace of a very rapid drawdown, supporting relative aggressiveness because, among other reasons, they may be concerned that a very rapid drawdown means the Afghan government might falter. Existing scholarship does not focus on issues of reluctant Presidents and hawkish Congresses. In general, there is an undue one-sidedness in current scholarship, both about the potential for Presidents more warlike than Congress, and to the legitimacy of concurrent

* Commissioner, Commission on Wartime Contracting in Iraq and Afghanistan, 20082011; Professor, University of Baltimore Law School. Further information on this statutorily created Commission and its televised hearings may be found on its website, www. wartimecontracting.org

1. For general treatments of the subject, see STEPHEN DyCUS ET AL., NATIONAL SECURITY

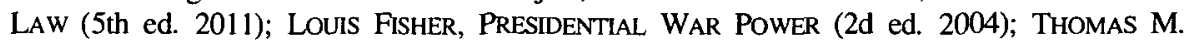
Franck et al., Foreign Relations and National Security Law: Cases, Materials and Simulations (3d ed. 2008); Michael. J. Glennon, Constitutional Diplomacy (1990); Louis HeNkIN, Foreign AfFaIRS AND the United States CONSTITUTION (2d ed. 1997). 
resolution mechanisms in bridging gaps between the President and the Congress.

Take two speculative yet real-world paths. In the simpler case, Congress enacts, either in legislation based on enumerated constitutional powers or on appropriated spending laws, an insistence on threatening to slow down a drawdown. In the Afghan war, the President has started a relatively swifter troop drawdown from 2012 to the mid-2010s. ${ }^{2}$ If the developments in Afghanistan are unacceptable, a President reluctant to keep significant troop levels in the field may face aggressive figures in Congress, with support from military commanders, who consider it necessary not to let troop levels fall too rapidly. ${ }^{3}$ This raises a controversy about whether a "hawkish" congressional appropriation or enactment provision interferes unconstitutionally with the Commander in Chief's disposition of forces. The author has discussed the issues of a hawkish Congress and a reluctant President in a recent article. ${ }^{4}$

In the more complex and interesting case, the reluctant President is significantly interested in acting jointly with the Congress. He looks for a process, established in the form of a legislative mechanism, which compromises with the hawkish congressional opposition. That way, the opposition does not enact a more rigid, if simpler, provision that unconditionally slows down a rapid drawdown, thereby forcing an immediate, perhaps unnecessary, confrontation over congressional power. Instead, this lets future events on the ground decide what happens.

So, he and the Congress use a statutory mechanism that is seen elsewhere in war powers. ${ }^{5}$ Congress votes freestanding enactments using its constitutionally enumerated war powers, or a condition on the year's defense appropriations, allowing drawdowns at a rapid pace for now. Rather, Congress includes in those laws a statutory mechanism that does

2. See generally SETH G. JONES, IN THE GRAVEYARD OF EMPIRES: AMERICA'S WAR IN Afghanistan (2009) [hereinafter Jones]; Michael E. O'Hanlon \& Hassina SherJan, TOUghing It OUT IN AfGHANISTAN (2010); 'AHMEd RASHID, DESCENT INTO ChaOS: THE U.S. and the Disaster in Pakistan, Afghanistan, and Central Asia (2009) [hereinafter RASHID]

3. As early as 2009-2010, President Obama drew his support for a surge of troops into Afghanistan from a coalition of Republicans and centrist Democrats, whereas the coalitions for virtually all his other controversial policies involved Democrats overcoming Republican opposition. For an overall treatment of President Obama's ambivalence about the large escalation in sending troops to Afghanistan, see BOB WOODWARD, OBAMA's WARS (2010).

4. See Charles Tiefer, Can Congress Make a President Step Up a War?, 71 LA. L. REv. 391 (2011) [hereinafter Tiefer, Stepping $U p$ ]

5. See Charles Tiefer, The Constitutionality of Legislative Vetoes in Foreign Affairs After Chadha, and of Requiring Congressional Assent Before First Use of Nuclear Weapons, in First Use of NuClear Weapons: UNDER the Constitution, Who Decides? (Peter Raven-Hansen ed., 1987), reprinted in ThOMAS M. Franck \& MiChaEL J. GlenNon, Foreign Relations and National SeCurity LaW: Cases, Materials, and Simulations 728-732 (2d ed. 1993). 
authorize the President to carry out, for the next year, his projected drawdown. However, that provision also states that the drawdown shall stop, upon a concurrent resolution of the House and Senate - that is, a vote of the two chambers not subject to presidential veto. So, a drawdown can go forward on the presidential schedule, but he has agreed to let the two Houses of Congress stop it. Although the legislative veto mechanism is not generally known to the public, this mechanism has definitely been used since the mid-twentieth century to balance broad initiations of war powers for the President with a channel for potential checks by Congress.

Both sides may find common ground that drawdowns of troop strength in Afghanistan may be allowable if, but only if, capable of rethinking based on changing conditions as time goes by. So, Congress may authorize relatively rapid presidential drawdowns grudgingly on condition of Congress having power to conduct such rethinking, if the military commanders express alarm at developments in Afghanistan during the following months.

Staying with this second case, suppose the reluctant President is disinclined to have a head-on clash with the hawkish Congress - in other words, for practical purposes, rather than force Congress to make good on its threat, he accepts it has power. He accepts that it could adopt freestanding legislation using enumerated powers, or an appropriation provision, not authorizing and in fact slowing down a projected drawdown. Instead, he avoids the head-on clash by signing into law a provision to authorize his projected drawdown subject to legislative veto by Congress with lingering suspicion on both sides yet a sigh of relief at balancing their disagreeing positions and moving forward jointly for the present. ${ }^{6}$ Before and after enactment, critics may say the mechanism violates INS $v$. Chadha - the Supreme Court decision invalidating the legislative veto in a domestic context of powers delegated by Congress, not a war powers context. What does such a mechanism have in the way of constitutional support?

This analysis shines a new light on the constitutionality of mechanisms for the long wars in general (such as the Iraq war) as well as the Afghan war in particular. In recent years, wars have received analysis primarily just as to incidentals. Critics of controls on Presidents have developed their

6. For a sum-up of discussions of such a mechanism, see Daniel George, Note, That Is What We Said, But This Is What We Meant: Putting the Meaning Back into Use-of-Force Legislation, 78 GEO. WASH. L. REv. 942, 959 n.103 (2010) (citing Jacob E. Gersen \& Eric A. Posner, Soft Law: Lessons from Congressional Practice, 61 STAN. L. REv. 573, 578, 607$608(2008))$.

7. Immigration and Naturalization Serv. v. Chadha, 462 U.S. 919 (1983).

8. See generally Charles Tiefer, War Decisions In the Late 1990s by Partial Congressional Declaration, 36 SAN DIEGO L. REv. 1 (1999) [hereinafter Tiefer, War Decisions].

9. Note, Recapturing the War Power, 119 HARV. L. REv. 1815 (2006). 
positions $^{10}$ on a range of war contexts" in the "global war on terror." These issues include commission trials, ${ }^{13}$ detention and interrogation treatment, ${ }^{14}$ and eavesdropping. ${ }^{15}$

To understand the support for the President against congressional war powers (manifested in this article by a legislative veto mechanism), there is "a more pro-Executive approach," as Professor John C. Yoo noted, "such as the one promoted by scholars such as Robert Bork, Henry Monaghan, Eugene Rostow, Phillip Bobbitt, Robert Turner, and [Professor Yoo himself]. ..."16 Supporters $^{17}$ of stronger presidential ${ }^{18}$ war powers, ${ }^{19}$ such as Professors Yoo and Sidak among many others, have drawn on overall ${ }^{20}$ sources $^{21}$ from the past. ${ }^{22}$

10. Charles Tiefer, Veering Right: How the Bush Administration Subverts the LAW FOR CONSERVATIVE CAUSES (2004).

11. David Gray Adler, George Bush and the Abuse of History: The Constitution and Presidential Power in Foreign Affairs, 12 UCLA J. INT'L L. \& FoREIGN AfF. 75, 120-130 (2007).

12. See, e.g., Curtis A. Bradley \& Jack L. Goldsmith, Congressional Authorization and the War on Terrorism, 118 HARV. L. REV. 2047 (2005); but see David Abramowitz, The President, the Congress and the Use of Force: Legal and Political Considerations in Authorizing Use of Force against International Terrorism, 43 HARV. INT'L L.J. 71 (2002) (discussing how actual compromise on the 9/14/2001 resolution authorizing use of military force moderated presidential power; see also Authorization for Use of Military Force (AUMF), Pub. L. No. 107-40, 115 Stat. 224 (2001)).

13. Doran G. Arik, Note, The Tug of War: Combatant Status Review Tribunals and the Struggle to Balance National Security and Constitutional Values during the War on Terror, 16 J.L. \& POL'Y 657 (2008).

14. For general background, see, for example, Diane Marie Amann, Abu Ghraib, 153 U. PA. L. REv. 2085 (2005).

15. Christopher M. Ford, Intelligence Demands in a Democratic State: Congressional Intelligence Oversight, 81 TUL. L. REv. 721 (2007); Heidi Kitrosser, Congressional Oversight of National Security Activities: Improving Information Funnels, 29 CARDOZO L. REv. 1049 (2008); U.S. DEP'T OF JuSTICE, LEGAl AuTHORITIES SUPPORTING THE ACTIVITIES of the National Security AgenCy Described by the President (2006), available at http://www.justice.gov/opa/whitepaperonnsalegalauthorities.pdf

16. John C. Yoo, UN Wars, US War Powers, 1 CHI. J. INT'L L. 355, 364 (2000) (citing works by each of the named figures).

17. John C. Yoo, The Power of War and Peace: The Constitution and Foreign AFFAIRS AFTER 9/11 (2005); John C. Yoo, The Continuation of Politics by Other Means: The Original Understanding of War Powers, 84 CALIF. L. REv. 167 (1996).

18. See, e.g., Michael B. Mukasey, National Security and the Rule of Law, 32 HARV. J.L. \& PuB. POL'Y 831 (2009); John C. Yoo, War and the Constitutional Text, 69 U. CHI. L. REV. 1639 (2002).

19. See, e.g., Philip Bobbitt, War Powers: An Essay on John Hart Ely's War and Responsibility: Constitutional Lessons of Vietnam and Its Aftermath, 92 MiCH. L. REV. 1364 (1994); J. Gregory Sidak, To Declare War, 41 DukE L.J. 27 (1991).

20. Even the strong believers in presidential power would let Congress prevent or stop an intervention by denying it funding. See e.g., John C. Yoo, Kosovo, War Powers, and the Multilateral Future, 148 U. PA. L. REV. 1673 (2000).

21. Robert H. Bork, Erosion of the President's Power in Foreign Affairs, 68 WASH. U. L. QuARTERLy 693 (1990); J. Gregory Sidak, The President's Power of the Purse, 1989 
However, there has been a one-sided neglecting of constitutional analysis about just what role a hawkish Congress may play in the core issue of the keeping up the troop levels in a war zone. For that matter, that has been insufficient analysis of a mechanism like a legislative veto, particularly after the recent actions Congress took - short of full signedinto-law enactments, yet sometimes impactful nonetheless - as to the use of force in Kosovo in 1999, Iraq in 2007,,$^{23}$ and Libya in $2011^{24}$ (although there have been some important articles in 2011-2012 about use of force in Libya). ${ }^{25}$ This article culminates a trilogy of articles by the author on such war powers issues newly raised by novel constitutional aspects of the Iraq and Afghan wars. ${ }^{26}$

How realistic is it to analyze war situations beyond the commonplace example of Congress not authorizing, or stopping, hostilities? The author has developed this approach while serving as a Commissioner in 2008-2011 on the federal Commission on Wartime Contracting in Iraq and Afghanistan established in 2008 by Congress. ${ }^{27}$ This Commission had about two dozen televised hearings, and issued interim and special reports. The Commission's work on wartime contracting addresses, inter alia, a practical understanding of the interactions between Congress, drawdowns, and the Afghan war. Also, the author performed congressional service related to war powers issues before that. ${ }^{28}$

DUKE L.J. 1162 (1989).

22. For example, Professor Sidak expounds how President Hayes in 1879 used his veto against appropriations bill riders forbidding the Army to protect black voters, Sidak, supra note 19, at 1218-1219.

23. Bruce Ackerman \& Oona Hathaway, Limited War and the Constitution: Iraq and the Crisis of Presidential Legality, 109 MiCH. L. REv. 447, 467-470 (2011).

24. Trevor W. Morrison, Forum and Response, Libya, "Hostilities," the Office of Legal Counsel, and the Process of Executive Branch Legal Interpretation, 124 HARV. L. REV. FORUM 62 (2011).

25. Note, Separation of Powers - War Powers Resolution - Abama Administration Argues that U.S. Military Action in Libya Does Not Constitute "Hostilities,", 125 HARV. L. REV. 1546 (2012); John R. Crook, Note, U.S. Military Actions in Libya Raise Questions of Domestic Legal Authority; House Resolution Rebukes President for Noncompliance with War Powers Resolution, 124 AM. J. INT'L L. 574 (2011).

26. See Tiefer, Stepping Up, supra note 4; Charles Tiefer, Can Appropriation Riders Speed Our Exit from Iraq?, 42 STAN. J. INT'L L. 291 (2006) [hereinafter Tiefer, Appropriation Riders - Iraq).

27. Full information about the Commission is available at http://www. wartimecontracting.gov/.

28. As Solicitor of the House of Representatives, the author personally represented the House of Representatives in a number of constitutional cases on national security. See, e.g., Am. Foreign Serv. Ass'n v. Garfinkel, 490 U.S. 153 (1989) (vacating ruling striking down as unconstitutional a classified information provision in an appropriation bill), on remand, 732 F. Supp. 13 (D.D.C. 1990). The House brief addressed the constitutionality of the appropriation rider in that case, while also arguing the mootness issue which the Court accepted. The issues were nicely treated in Michael Glennon, Publish And Perish: 
Part I looks at the first issue, as to a hawkish Congress outright stopping a draw down by legislation. This is different from the provisions, analyzed much more often, by which a Congress opposed to hostilities may deny the President the authorization to fight. Weighing the arguments, the better view surveys the diverse examples of history, and it treats, as valid, congressional enactments that stop a troop drawdown out of the war zone. ${ }^{29}$ Because some of the issues about a hawkish Congress's powers were developed in a previous article by the author, readers who want further treatment of the issues in Part I should look at that previous article. ${ }^{30}$ Such readers would be disappointed if seeking in Part III more treatment of the same issues about the reluctant President and the hawkish Congress as in Part I.

Rather, Part II looks at the different question: May Congress take impactful steps by enacting a "concurrent resolution mechanism," with the President's support, for a potential later bicameral resolution stopping a drawdown - a mechanism the critics would call an unconstitutional "legislative veto"?

Part II starts with the clash of functionalist and formalist approaches to separation of powers: the functionalism of Youngstown Sheet \& Tube Co. $v$. Sawyer ${ }^{32}$ vs. the formalism of Chadha. A close reading of Chadha shows it does not fully resolve the role of concurrent resolution mechanisms in war

Congress's Effort To Snip Snepp, Before and AFSA, 10 MiCH. J. INT'L L. 163 (1989). The author also served as Special Deputy Chief Counsel on the House Iran-Contra Committee.

29. Impressive articles that shows congressional war powers far stronger than argued by those supporting the positions taken by President Bush include David J. Barron \& Martin S. Lederman, The Commander in Chief at the Lowest Ebb - Framing the Problem, Doctrine, and Original Understanding, 121 HARV. L. REv. 689, 756 n.201 (2008); Jules Lobel, Conflicts Between the Commander in Chief and Congress: Concurrent Power over the Conduct of War, 69 OHIO ST. L.J. 391 (2008).

30. Tiefer, Stepping Up, supra note 4.

31. Abner S. Greene, Checks and Balances in an Era of Presidential Lawmaking, 61 U. CHI. L. REv. 123, 187-188 (1994).

32. Youngstown Sheet \& Tube Co. v. Sawyer, 343 U.S. 579 (1952) [hereinafter Youngstown]. Justice Jackson's "zone of twilight" analysis, see id. at 637 (Jackson, J., concurring), has been recognized in other contexts, like that of the 1995 Mexican peso bailout, as befitting the post-Cold War situation of Presidents who propose national security actions that elicit neither clear authorization nor clear prohibition from a Congress, and a public, ambivalent about foreign involvements. See, e.g., Russell Dean Covey, Adventures in the Zone of Twilight: Separation of Powers and National Economic Security in the Mexican Bailout, 105 YaLE L.J. 1311 (1996); James D. Humphrey II, Note, Foreign Affairs Powers and "The First Crisis of the 21" Century": Congressional vs. Executive Authority and the Stabilization Plan for Mexico, 17 MICH. J. INT'L L. 181 (1995). For recent treatments of the Bush administration's initiatives in light of Youngstown, see, for example, Kathryn L. Einspanier, Burlamaqui, the Constitution, and the Imperfect War on Terror, 96 GEO. L. J. 985 (2008); Joseph C. Hansen, Murder and the Miliary Commissions: Prohibiting the Executive's Unauthorized Expansion of Jurisdiction, 93 MINN. L. REv. 1871 (2009); Mark D. Rosen, Revisiting Youngstown: Against the View that Jackson's Concurrence Resolves the Relation Between Congress and the Commander in Chief, 54 UCLA L. REV. 1703 (2007).' 
powers. Moreover, many academics concur that Chadha does not bar such mechanisms in war powers.

Then, that Part builds the case for concurrent resolution mechanisms in war powers by going into the background, some of which is little-known, of such mechanisms. The best known such mechanism, Section 5(c) of the War Powers Resolution, ${ }^{33}$ enacted at the end of the Vietnam War, ${ }^{34}$ has been included in the extensive discussion of the War Powers Resolution. ${ }^{35}$ Some academics assume that Chadha must have rendered Section 5(c) of the War Powers Resolution invalid. However, Professor Abner S. Greene cites a number of eminent authorities to observe that " $[t]$ here is fairly strong support in the literature for the constitutionality of [S]ection 5(c) of the War Powers Resolution, which requires that the President remove troops from hostilities pursuant to a concurrent resolution." ${ }^{36}$ Since his article, there have been yet more eminent authorities agreeing that Section 5(c) of the War Powers Resolution is constitutional. ${ }^{37}$ In brief, Chadha concerns domestic legislation delegating administrative powers to the executive, not the more fluid shared war powers.

Moreover, the literature has failed to pay sufficient attention to how Section 5(c) of the War Powers Resolution followed many prior similar mechanisms, probably because there is no obvious trail leading back to these predecessor provisions, notwithstanding the provisions' importance. ${ }^{38}$

33. War Powers Resolution, Pub. L. No. 93-148, 87 Stat. 555 (1973), 50 U.S.C. $\S \S 1541-1548$ (2006). For current insight into the War Powers Resolution as a whole, see Michael J. Glennon, Comment, The War Powers Resolution, Once Again, 103 AM. J. INT'L L. 75 (2009).

34. John Hart Ely, The American War in Indochina, Part I: The (Troubled) Constitutionality of the War They Told Us About, 42 STAN. L. REV. 877 (1990); John Hart Ely, The American War in Indochina, Part II: The Unconstitutionality of the War They Didn' $i$ Tell Us About, 42 STAN. L. REV. 1093 (1990).

35. See, e.g., JOHN HART ElY, WAR AND RESPONSIBILITY (1993); 'Ronald D. Rotunda, The War Powers Act in Perspective, 2 Mich. L. \& POL'Y Rev. 1 (1997); Cyrus L. Vance, Striking the Balance: Congress and the President Under the War Powers Resolution, $133 \mathrm{U}$. PA. L. REV. 79 (1984); Bennett C. Rushkoff, Note, A Defense of the War Powers Resolution, 93 Yale L.J. 1330 (1984); Martin Wald, Note, The Future of the War Powers Resolution, 36 STAN. L. REv. 1407 (1984); Bobbitt, supra note 19; Note, Realism, Liberalism, and the War Powers Resolution, 102 HARV. L. REV. 637 (1989).

36. Greene, supra note 31, at 193 n.259 (citing Stephen L. Carter, The Constitutionality of the War Powers Resolution, 70 VA. L. REV. 101, 130-132 (1984); Gerhard Casper, Constitutional Constraints on the Conduct of Foreign and Defense Policy: A Nonjudicial Model, 43 U. CHI. L. REv. 463, 484-485 (1976); and John Hart Ely, Suppose Congress Wanted a War Powers Act That Worked, 88 Colum. L. REv. 1379, 1395 (1988)).

37. See Tiefer, War Decisions, supra note 8, 36 SAN DIEGo L. REv. at 30-31 nn.133135 (citing, inter alia, the 4th edition of DYCUS ET AL, supra note 1, and Michael J. Glennon, The Constitution and Chapter VII of the United Nations Charter, 85 AM. J. INT'L L. 74 (1991)).

38. A rare current example is Robert Gray Bracknell, Real Facts, "Magic Language", the Gulf of Tonkin Resolution, and Constitutional Authority To Commit Forces to War, 13 
These provisions reveal the fundamental logic of such mechanisms: the two elected branches have much more flexibility as to war powers than as to domestic legislation delegating authority. And Presidents - including the reluctant Presidents - need a way to go ahead with war powers steps, including drawdowns, without denying Congress agreed-upon means for stopping those steps when the situation alters greatly.

From another angle, in the past dozen or so years, the concept of potent actions by one or both Houses of Congress, pursuant to Section 5(c) of the War Powers Resolution or otherwise, has come into play repeatedly. An important congressional step occurred as to the Kosovo war of $1999 .{ }^{39}$ Votes on important congressional steps occurred as to the Iraq War in 2007. Most recently, the House took significant votes as to the Libyan conflict in 2011. These steps did not involve full invocation of a concurrent resolution mechanism, and a rigid formalist might blow them off as only illustrative of politics, not constitutional war powers. However, they should instead be seen as meaningful. They had compelling democratic legitimacy. They show the history of war powers virtually up to the minute, and to paraphrase what Oliver Wendell Holmes said, a page of history (about war powers) is worth a volume of logic. ${ }^{40}$

Based on such past experience, there are different ways to conceptualize how a concurrent resolution mechanism works in war powers, different from the enactment process for congressionally enumerated powers or appropriations. Partly it comes from a kind of signaling in war powers not found in domestic delegation legislation. And, in the "democratic legitimacy" theory, the concurrent resolution has the democratic legitimacy that is proper to war powers decisions.

Secondly, in the "anticipated next step" theory the President may read the provision as anticipating that a concurrent resolution, if flouted, will elicit a next step soon - perhaps with grievous rejection of prerogative for the President - in the form of strong provisions in Congress's subsequent legislation or defense appropriations that the drawdown shall stop. ${ }^{41}$

The Conclusion treats how the issues for war powers analysis have changed from the classic ones to the new cutting-edge ones of the war in Afghanistan. It suggests the need for "suppleness" in war powers reasoning to keep up.

NEW ENG. J. INT'L \& COMP. L. 167, 208-209 n. 112 (2007).

39. Michael Benjamin Weiner, Note, A Paper Tiger with Bite: A Defense of the War Powers Resolution, 40 VAND. J. TRANSNAT'L L. 861, 889 (2007).

40. N.Y. Trust Co. v. Eisner, 256 U.S. 345, 349 (1921).

41. On confirmation in appropriations, see Note, Recapturing the War Power, 119 HARV. L. REV. 1815, 1820-1821 (2006). 


\section{BACKGROUND TO THE AFGHAN WAR}

In 2001, in response to the 9/11 terrorist attacks, Congress adopted the authorization for force against the Taliban regime just three days after the attacks, ${ }^{42}$ without any way to foresee a full-scale counterinsurgency still facing a tough enemy in the next decade. ${ }^{43}$ In 2001-2002, the United States' striking victories chased the Taliban leadership out of power in Afghanistan, although the chance to capture them was missed. ${ }^{44}$ At that date, a relatively limited American commitment could have rooted the base of the Taliban out, and made any comeback by them difficult if not impossible.

This sequence that followed may be cited either by congressional hawks when they object to what they deem an overhasty troop drawdown, or by a reluctant President who says it is long overdue to draw down. Instead of blocking a Taliban comeback in the 2000s, the Bush administration instead initiated a policy called "light footprint." 45 This meant deploying only about 8,000 troops who did not engage in peacekeeping. As Afghanistan expert Seth Jones writes, “'light footprint' . . . would prove to be a serious misstep that contributed to the collapse of governance in Afghanistan." ${ }^{46}$ Moreover, the shift in resources and attention from Afghanistan to Iraq grew irreversible, as the insurgency there got going from 2003 on, and deprived the Afghan war of the means of success. So, the Taliban came back. ${ }^{47}$ NATO tried a "clear, hold, and build" strategy, but "low levels of troops made it virtually impossible to hold territory in Afghanistan's violent south. ${ }^{, 48}$ The Bush administration continued to take away all the key resources for use in the Iraq war. As late as 2008, only 30,000 American troops were deployed in Afghanistan. ${ }^{49}$ As a result, the Taliban grew in area of involvement, armed strength, and levels of violence. They were seen as winning. ${ }^{50}$

Under the Obama administration, a double infusion of troops took place. The military sought the forces needed for a counterinsurgency mission, with the goal of protecting the Afghan civilians to make the

42. Authorization for Use of Military Force, Pub. L. No. 107-40, 115 Stat. 224 (2001)

43. See Stephen I. Vladeck, Ludecke's Lengthening Shadow: The Disturbing Prospect of War Without End, 2 J. NAT'L SECURITY L. \& POL'Y 53 (2006).

44. JONES, supra note 2 at 97.

45. Id. at 115 .

46. Id.

47. Sikander Ahmed Shah, War on Terrorism: Self Defense, Operation Enduring Freedom, and the Legality of U.S. Drone Attacks in Pakistan, 9 WASH. U. GLOB. STUD. L. REV. 77, 81-82 (2010).

48. JONES, supra note 2, at 254.

49. Id. at 301 .

50. See id. at 306. 
country strong and secure enough for the Taliban to lose their hold. The President ordered a first infusion in spring 2009, fulfilling campaign promises to shift the focus from Iraq to Afghanistan.

An intense debate broke out over a military proposal for a second infusion to occur mostly during 2010, especially for offensives in the south and east. ${ }^{51}$ Strong forces within the Obama administration opposed the enlarged commitment as did important figures in Congress. The "opposition" to the second infusion had become a core in the President's own party led by Vice President Joseph Biden, who had championed a different strategy called "counterterrorism-plus." ${ }^{52}$ On the other side, hawkish supporters of a strong commitment included some military commanders and the Republican Party in Congress, not yet in charge of either chamber as it was from 2011 on. The White House ordered this second commitment, but with statements about a drawdown to begin in 2011 and to hand over completely the combat mission to the Afghans in 2014. ${ }^{53}$ Consistent with that, the White House began anticipating substantial drawdowns in each year until the handing over of the combat mission.

Thereafter, the tension lay between congressional (and military) "hawks" and the reluctant President. Senator John McCain led the congressional "hawks," reflecting his very substantial expertise and experience about war. The arguments on both sides foreshadow the arguments thereafter about a faster and larger drawdown vis-à-vis a slower and smaller one. In 2010, the side favoring more of a drawdown ${ }^{54}$ argued that "[r]ather than investing so many of our resources in Afghanistan, we should pursue a comprehensive, global counterterrorism strategy.",55 By 2011, with troop levels having peaked, the side favoring more of a drawdown could argue from successes, such as reduced levels of violence in the country as a whole and a successful military effort against the Taliban

51. WOODWARD, supra note 3, at 157-159.

52. Id. at 159-160, 234-236.

53. Mark Landler \& Helene Cooper, Obama To Announce Plans for Afghan Surge Pullout, N.Y. Times, June 21, 2011, at A13.

54. A counterterrorism campaign, in this context, means using drones, special operations forces, and other specific resources to take down al Qaeda leaders, and perhaps some of the Taliban leadership. The Air Force may use bases in the country or may augment these as the war goes on by more reliance on neighboring countries. This strategy places maximum emphasis on training Afghan army and police for an earlier turnover from the American forces of the struggle with the Taliban. Counterterrorism means not necessarily keeping more regular military forces for fighting, beyond what the specific missions need to hit terrorist figures and what is needed to secure bases within Afghanistan for those missions and to keep the Taliban from taking over the country. See WoODWARD, supra note 3, at 234236.

55. Press Release, Bipartisan Group of Legislators Writes President To Oppose Afghanistan Troop Increase, SEN. TOM HARKIN (Dec. 2. 2009), available at http://harkin. senate.gov/press/release.cfm? $\mathrm{i}=320378$ (emphasis added). 
strongholds in southern Afghanistan. Furthermore, those supporting such presidential reluctance could argue that the United States, with high level of debt and deficit inherited from the 2000s and a grueling recession, cannot afford the cost; that the large American cost, in killed and wounded, cannot be accepted; and that the American military cannot take the strain and distraction of this one long, large-scale war. In terms of local effects, ${ }^{56}$ they argue the war in the region acts to further destabilize, not bring stability. ${ }^{57}$ Some argue that a larger commitment is unsustainable, and, so, will not persuade others we intend to sustain it, with their expectations of our eventual total departure working against us. ${ }^{58}$

On the other hand, the hawks who might stop a drawdown could say that the announcement of a drawdown schedule itself undermines the American position, as the Afghan government and people, and neighboring states, treat us as short-termers and pay less heed to what we say or do. ${ }^{59}$ By not making a premature drawdown, it may be that only a few more years of large military forces will be needed in Afghanistan, because of military successes by the American forces. ${ }^{60}$ Conversely, signs of instability in Afghanistan may suggest going ahead with a drawdown might even threaten an Afghan government collapse.

The issue is not which side is right as a matter of policy about the Afghan war. Rather, this illustrates why a President may be reluctant and a Congress may be hawkish. It also illustrates why they might both look for a compromise in the form of a concurrent resolution mechanism letting a drawdown proceed subject to being stopped by a concurrent resolution based on changing realities on the ground.

\section{WHY CONGRESS MAY STOP, OR THREATEN TO STOP, A PROJECTED TROOP DRAWDOWN}

Much has been written about the more familiar type of Congress: the Congress that is less hawkish than an aggressive President and seeks to prevent or end wars. In contrast, comparatively little has been written about the Congress that is more hawkish than a reluctant President - a hawkish Congress that seeks to stop a drawdown. While there is less familiarity

56. Material for all sides can be found in RASHID, supra note 2 .

57. Id.

58. Robert Grenier, the former CIA station chief in Islamabad during the 2001 invasion of Pakistan, testified at a 2009 Senate hearing, "What we are currently doing I believe is not sustainable either by us or by the Afghans." See Statement of Sen. Russell Feingold, Correcting the Myths in the Debate over Afghanistan, 10/28/09 ConG. DOCUMENTS, 2009 WLNR 21527912 (Westlaw).

59. David Kilcullen, The accidental Guerrilla: Fighting Small Wars in the Midst OF A Big ONE (2009).

60. O'Hanlon \& Sherjan, supra note 2 , at 74. 
with the hawkish Congress, it is not an unknown phenomenon. Professor Sidak has summed up some major examples.

Today, of course, we are so accustomed to thinking of Presidents as more hawkish than Congress that the hypothetical of a dovish President would strike many as preposterous. Yet, history provides a number of commonly ignored examples: John Adams resisted calls for a declaration of war against France in 1798 and instead sought authority for the limited and undeclared Quasi-War; James Madison was ambivalent about declaring war on Britain in 1812; Grover Cleveland in 1896 rebuffed the proposal by various members of Congress to declare war on Spain; William McKinley in 1898 reluctantly conceded to the same war fervor; and Woodrow Wilson successfully campaigned for reelection in 1916 on the slogan, "He kept us out of war."

A recent pair of articles presents an enlightening treatment of Congress's powers of the particular powers of the kinds of uses of troops, such as their deployment or redeployment. Professor Saikrishna Prakash presents a comprehensive argument that Congress has an enumerated power to direct troop deployments; ${ }^{62}$ Professor Michael Ramsey critiques this position. ${ }^{63}$ Among other points, to show "Congress's power to escalate and de-escalate," meaning that "Congress not only can decide the type of war to be fought, but also can decide the level of force brought to bear in a war," Professor Prakash recounts the classic account of a hawkish Congress: "Congress gradually escalated the use of the armed forces against France [in 'the Naval War of 1798']."64

Professor Prakash cites this in a full treatment of Congress's enumerated enactment powers, including its power to block deployments or de-escalate, from sources in the Constitution's text, formative influences such as English precedents, and early history. Notably, he argues that Congress has a number of enumerated constitutional powers, quite apart from spending control, to escalate or to de-escalate wars. These include the powers to raise and support armies, exercise exclusive legislation over military construction, regulate the armed forces and militia, regulate deployments, define the levels of uses of force and types of war, and set a war's objectives. ${ }^{65}$

61. Gregory Sidak, To Declare War, 41 DUKE L.J. 27, 85-86 (1991) (footnotes omitted).

62. Saikrishna Bangalore Prakash, The Separation and Overlap of War and Military Powers, 87 TEX. L. REv. 299 (2008).

63. Michael D. Ramsey, Response: Directing Military Operations, 87 TEX. L. REv. SEE ALSO 29 (2009).

64. Prakash, supra note 62, at 345.

65. Id. at 331-351. 
A. The Issue of Form: Does It Truly "Condition" an Appropriation To Stop a Drawdown? Or Is It a Disguised Mandate To Spend?

There is an issue, first, that Congress's war power via conditioning of appropriations, or legislation, has no relevance to stopping a drawdown, for reasons of form. To put it differently, for Congress to stop a drawdown may be a mandate that the President must use the forces Congress gives him, and, a mandate to spend the money - not a condition or negative on him. The usual issue raised in the context of war powers is whether Congress may preclude a war or other hostilities that involve an obvious outlay of expenditures for a new war the President intends, by a legislated negative on his authority or by providing that "none of the funds in this appropriation" may be used for such a war. So, as a matter of form, some might say that stopping a drawdown, in contrast to stopping a new war, does not so much bar the use of more forces or more funds, as mandate the use of forces or the spending of more funds to continue having the contemporaneous higher level of troops in the war zone. So, even if it is phrased in the negative ("none of the funds in this appropriation may be used for the projected drawdown"), it is, as a practical matter, a mandatory spending requirement (that is, its straightforwardly-structured form would be that "the President is mandated to use the forces and to spend the funds in this appropriation on keeping up the troop level").

This is not to argue (yet) about whether Congress is excessively interfering with the Commander in Chief. This is only about the issue of whether the condition is truly, in form, a negativing one. To put it differently, deciding the question of form leaves unresolved whether the condition invades the Commander-in-Chief power. A provision may be in negativing form, such as that the President could spend no funding "on Marine small-unit combat in Helmand Province" would properly be in negativing form but would nonetheless raise serious of Commander-inChief issues.

The provision is properly in negative form, as to, say, prohibiting a drawdown in Afghanistan (or, in 2007, in Iraq), because a drawdown is a new, vast, and distinct operation requiring new action and expenditure of freshly allocated billions of appropriated dollars for activity that differs from campaigning. The provision also does result, in the medium and long term, in less use of troops in the war zone and less spending. Still, in the next year, in form it negatives the new, vast, and distinct non-campaign actions and spending required for the drawdown operation.

This author, as part of his Commission's work, was on missions in Iraq reviewing the drawdown in Iraq both before and during its progress in 2009-2010, and was in Afghanistan during the period when a drawdown was being considered. Close familiarity with the activity of the Department of Defense in the war zone makes clear that a drawdown occurs as a new, 
vast, and distinct operation, using separate congressional authorization ${ }^{66}$ and enormous newly allocated expenditures and huge numbers of both civilian and military personnel, separate from campaigns against the enemy. It is like the mirror image of the preparation for a war. A drawdown means both a new, vast, and distinct troop movement out of the country back to the United States (or elsewhere); equally important, it also means a gigantic and very costly - relocation, assessment, and refurbishment, termed "reset," of equipment and material; and it means a gigantic - and very costly project of altering, and decommissioning, costly bases, camps, and other facilities. It means extensive planning, tremendous contractor work, and costs billions of dollars to make the concomitant changes in bases, in fleets of military vehicles, in the equivalent of whole chains of arsenals and warehouses of materiel, and in the contractor support for all this.

Although the drawdown presumably will, in the medium or long run, produce a net savings in operation costs because there will be fewer troops in the war zone, in the short term it uses new authority and is very costly in a new and distinct way. In any event the costs in the short term, and savings in the long term, are no more netted out in considering the form of a legislated enactment or an appropriation condition, than the potential longterm gain from hiring a thousand new IRS agents would be netted out from the short-term hiring costs in deciding whether Congress could properly legislate against, or decline to appropriate, for the hiring.

It is also irrelevant that in general the defense appropriation accounts used in wartime are provided as the very broadest and largest of line items in appropriation laws. Prohibitions work fine on matters that are within such large line items. Within the executive, the defense appropriations must be allocated, allotted, and sub-allotted so that the funds are there for the costs of each of the vast, new, and distinct aspects of the drawdown operation. As to form, Congress can legislate a prohibition or insert a condition to stop the drawdown by negativing the tapping for the drawdown of such allocations and allotments.

There is a related argument that stopping a drawdown is not a way a hawkish Congress can force a reluctant President to maintain the level of combat, because it leaves the President a backdoor option of reaching his de-escalation goal. The argument is that a reluctant President could undo the desired effect of maintaining the level of combat, because Congress may only prevent him from a drawdown of troops out of the war zone. The hawkish Congress would not be preventing him, as a matter of directing combat operations within Afghanistan, from taking the portion of troops marked for drawdown, and pulling them out of combat there. That is, he can make a kind of "internal drawdown" within Afghanistan by which he

66. The congressional defense authorization committees report an annual defense authorization bill. One would expect oversight, and specialized provisions, by the authorization law as to a drawback. 
moves out of the front line a percent of troops that he had marked out to bring home, but for which Congress has negatived spending on the drawdown operation. While not drawing them out of the Afghan war zone, he would move them to Afghanistan bases away from the combat (roughly speaking, in the regions of the north and west of the country), and thereby reduce the level of troops engaged in fighting.

This article does not evaluate this more extreme issue about whether Congress can regulate the President's power to make such an "internal drawdown" within the war zone as part of his powers to direct combat activity itself there. That presents the very separate question about what Congress may do as to combat arrangements, quite a different issue than whether, as a matter of form, a prohibition in legislation or an appropriations condition can negative the authorization or funding of a drawdown. Congress may take one step at a time, negativing a drawdown out of the war zone without grabbing for the Commander in Chief's tactical controls within the war zone.

Also, it may merely be noted that as a practical matter, the President would face enormous pressure if a hawkish Congress were joined by the military commanders in the field and up the chain of command, all deeming it gravely wrong to warehouse passively a group of the troops that Congress has kept in Afghanistan anyway. The military should, and will, understand a national decision, thrashed out by the President and Congress, that the time has come to reduce our role in the Afghan war by drawing down, vel non, United States troops out of the country. But that is very different from their accepting that part of the Army in Afghanistan would stay passively and uselessly in an ill-chosen part of Afghanistan, sitting on its hands, neither fighting nor leaving, doing nothing but burn up taxpayer funds, and, although relatively nearby, not helping their fellow combat forces taking casualties at the front. It is that practical matter of what the military would tolerate as sensible within its sphere of war zone, more than legal arguments as to form, that limit the likelihood of Congress needing to deal with a President's "internal drawdown" that kept forces sitting passively in Afghanistan.

This is absolutely not to say that all conditions on appropriations in war can be put properly in negativing form, or that the form resolves the constitutional Commander-in-Chief issues. Take a very serious stepping-up of a war, such as Congress directing that the army invade sanctuaries in neighboring Pakistan. Something superficially phrased as a negative condition, like "none of the funds in this appropriation shall be expended unless the Army goes into Pakistan" remains a disguised mandatory order of campaigning and expenditure. Unlike a drawdown-stopping condition, it does not achieve its objective by negativing a specifiable flow of funds to a new, vast, and distinct object. Unlike a drawdown, there would be no new, massive, and distinct expenditure just from the army not having the 
condition laid upon it, and, instead, just staying put and continuing as before to stay in Afghanistan and to keep out of Pakistan.

Rather, a hawkish Congress's condition that like "none of the funds in this appropriation shall be expended unless the Army goes into Pakistan" attempts to mandate the positive action and funding of new allotments and sub-allotments for the positive flow of funds, to achieve its newly sought object, namely, the invasion desired by the hawkish Congress. True, both stopping a drawdown and directing an invasion step up a war. But, as to which is in proper form as a negativing condition, the drawdown-stopper is properly in negativing form, and the invasion-orderer is not. It remains fair - and in fact, it is very important, and the right question, to ask - whether a hawkish Congress can stop a drawdown in light of presidential powers. To say the provision is in proper form does not at all answer whether a hawkish Congress can stop the drawdown planned by a reluctant President. But, at least it is in proper form for negativing appropriations.

\section{B. May Congress Stop a Drawdown in an Appropriation Provision?}

Just saying that, as a matter of form, Congress may put its stopping of a drawdown in terms of a statutory prohibition or appropriation condition only begins, rather than ends, the constitutional argument. Some who dispute that Congress may place their constitutional reliance on the President's general powers in what continues to be an authorized, legal war, particularly as to matters in the "active theater of war." prior article treated the basic considerations of this issue and so, here, it need only be treated here relatively briefly. An analysis may group, loosely, those Commander-in-Chief concerns into three groups: ${ }^{68}$ command, ${ }^{69}$ disposition of forces, and military campaigns. ${ }^{70}$ In the

67. Cf. Boumediene v. Bush, 553 U.S. 723, 769-771 (2008) (discussing the Court's refusal to extend federal habeas corpus to aliens in occupied Germany in Johnson $v$. Eisentrager, 339 U.S. 763 (1950), given the possibility of judicial interference in military affairs); but see Youngstown, 343 U.S. at 587 ("[T]hough 'theater of war' be an expanding concept [the Commander in Chief does not have] power as such to take possession of private property in order to keep labor disputes from stopping production.").

68. For a different way of evaluating the extent of infringement of a provision on the Commander-in-Chief issues, see Tiefer, Appropriation Riders - Iraq, supra note 26, at 320325.

69. Training of British Flying Students in the United States, 40 Op. Att'y Gen. 58, 61 (1941) ("the President's responsibility as Commander in Chief embraces the authority to command and direct the armed forces in their immediate movements and operations"). In an apt distinction:

Congress ... also has a distinct enumerated power to provide for armies and navies, and to prescribe the uses to be made for them. There is nothing inconsistent between this proposition and another one, which arises from a combined reading of the declaration of war clause and the President's power as Commander-in-Chief. This is the proposition that under those circumstances in which Congress has affirmatively embraced a commitment to belligerent activities 
drawdown context, the President's relevant core concern consists of the disposition of forces, with effect on campaigning. This is the President's power, without legislative interference, to decide where to employ the armed forces in wartime - that is, whether they should be in the United States, or, in the war zone of Afghanistan.

The clearest Supreme Court comment on this subject occurred in Fleming v. Page:

As commander-in-chief, [the President] is authorized to direct the movements of the naval and military forces placed by law at his command, and to employ them in the manner he may deem most effectual to harass and conquer and subdue the enemy.

For Congress to stop a drawdown derives strength from its past use of its potent powers to distinguish between authorized and non-authorized levels of war. ${ }^{72}$ A classic condition attaching to military appropriations occurred during the Indochina War in the 1970s that "none of the funds shall be used" for ground operations across the borders in Laos and Cambodia. ${ }^{73}$ Note the distinction Congress made between air and ground operations, a kind of distinction later made in a different form as to Kosovo in 1999 and Libya in 2011 - in effect, defining the level of combat by stopping the stepped-up (ground operations) level while letting the lesser (air operations) level go unchallenged. The Boland Amendments during President Reagan's proxy war against Nicaragua in the $1980 \mathrm{~s}^{74}$ by Contras

overseas on a sustained basis, it may not presume to dictate the minute strategy and tactics of the President's conduct of the authorized enterprise.

Symposium, The President's Powers as Commander-in-Chief Versus Congress' War Power and Appropriations Power, 43 U. MIAMI L. Rev. 17, $46-47$ (1988) (Prof. William Van Alstyne).

70. Appropriations--Marine Corps--Service on Battleships, 27 Op. Att'y Gen. 259, 260-261 (1909) (upholding as constitutional a congressional provision that eight percent of detachments aboard naval vessels consist of Marines).

71. Fleming v. Page, 50 U.S. (9 How.) 603, 615 (1850).

72. The potent "No Money" Clause of the Constitution, U.S. CONST. art. I, $\$ 9, \mathrm{cl} .7$, provides that "No Money shall be drawn from the Treasury, but in Consequence of Appropriations made by Law." The Framers placed this clause with, and worded it sternly like, the other emphatic interdicts in Art. I, $\$ 9$, rather than with the general affirmative powers in Art. I, §10. See Office of Pers. Mgmt. v. Richmond, 496 U.S. 414, 427-428 (1990).

73. Louis Fisher, Presidential War Power 142-143 (2d ed. 2004)

74. See Harold HongJu Koh, The National Security Constitution: Sharing Power After the Iran-Contra Affair (1990); Andrew W. Hayes, Note, The Boland Amendments and Foreign Affairs Deference, 88 CoLUM. L. REv. 1534, 1568-1569 (1988). This came after the disclosure of CIA involvement in mining Nicaraguan harbors. In 1982, the Boland Amendment to an appropriation disapproved of funding to groups involved with overthrowing the government of Nicaragua. See id. at 1567, $1567 \mathrm{nn} .241-243$. 
illustrate Congress's flexibility in defining the level of wars ${ }^{75}$ in many respects. $^{76}$ Again the Congressional specification did not just amount to setting an overall amount, but showing another kind of Congressional power both to de-escalate and to escalate.

As noted, Professor Prakash has gathered numerous early authorities about Congress's power. The text and original understanding of the Constitution let Congress define the level of hostilities, including escalation and de-escalation. The author's previous article did so in detail for the past two centuries. These include specific examples of a hawkish Congress stepping up a war, such as stepping up the Naval War of 1798. Professor Prakash concludes, "rather than having a power to make a binary, one-time decision about whether to wage war, Congress may adjust the use of force against an enemy.","

And, some particular examples show Congress specifying "hawkish" (albeit sometimes in a very loose and general sense) steps, during a conflict. Professor Lobel's work ${ }^{78}$ shows the hawkish (on this issue) "Radical Republican" Congress of the Civil War enacting legislation to push President Lincoln to a stepping-up as to the war zone. Notably, in the Second Confiscation Act, Congress legislated that the military would confiscate the property, and would free the slaves of rebels. ${ }^{79}$ The statute expressed the hawkish Congress's desire without delay to push further against the enemy in freeing slaves. By doing this too early, President Lincoln though this might embitter the South and even potentially alienate the border states. President Lincoln opposed what he considered the ill timing of the measure.

75. With President Reagan's acceptance and non-disputation on constitutional grounds (however much he disagreed with the provisions as not supporting his policy enough), Congress made controlling dispositions, again and again, of the funding for personnel and material for the Contra war. As Special Deputy Chief Counsel on the House Iran-Contra Committee, the author co-authored the chapter in the committee report on the Boland Amendments. Report of the Congressional Committees Investigating the Iran-Contra Affair, S. REP. No. 100-216; H.R. REP. NO. 100-433 (1987). For previous writings drawing on such service, see Charles Tiefer, The Semi-Sovereign Presidency 119-136, ch. 6, "The Persian Gulf War Authorization," (1994); George W. Van Cleve \& Charles Tiefer, Navigating the Shoals of "Use" Immunity and Secret International Enterprises in Major Congressional Investigations: Lessons of the Iran-Contra Affair, 55 Mo. L. REv. 43 (1990).

76. Boland IV allowed some funding, and Boland V went further. Hayes, supra note 74, at $1568 \mathrm{nn} .253-255$. Again, as with distinctions between "air" and "ground" war, the "humanitarian" aid prescription did not hold back funds in the Treasury. Rather, it enacted a control on operations in the war zone. Id. at 1569-1570.

77. Prakash, supra note 62 , at 347.

78. Jules Lobel, Conflicts Between the Commander in Chief and Congress: Concurrent Power over the Conduct of War, 69 OHIO ST. L.J. 391, 430-437 (2008).

79. See An Act To Suppress Insurrection, To Punish Treason and Rebellion, To Seize and Confiscate the Property of Rebels, and for Other Purposes, ch. 195, 12 Stat. 589-592 (1862). 
For a much-analyzed contemporary example, Congress debated with the Executive in the 1990s whether U.S. forces could take part in hostilities under United Nations command. ${ }^{80}$ The congressional insistence on dictating a non-United Nations command deeply intruded into the presidential direction of the chain of command. ${ }^{81}$ As it has turned out, Presidents have steered towards military alliance with the congressionallyfavored NATO, rather than a United Nations, structure, such as for Afghanistan starting in 2001 and Libya in $2011 .^{82}$ In effect, the President was declining to dispute Congress's instruction.

A provision for drawdown of the troops in a war - the Afghan war or other - touches on a concern of the Commander in Chief as to the disposition of forces, but does not amount to congressional dictation at that concern's core. Congress can stop a drawdown. Congress provides the authority and money for the troops to be in the war zone but not for a drawdown. Then, the Commander in Chief exercises his powers: he directs their command - by relations with the commanders - directs their disposition in the war zone - by giving orders as to where each unit will be - and, directs their campaigning - by giving orders about their engaging with the enemy. Congress is at a distance from all this, setting an overall level of hostilities, but as to everything finer-grained than that, not interfering. Further analysis of the issue of Part II may be found in the author's prior article on when a hawkish Congress may step up wars.

\section{ANALYZING A CONCURRENT RESOlUtion MECHANISM}

Now comes the other, more complex question about a compromise mechanism between the President and Congress: the validity of a concurrent resolution mechanism in war powers. In the course of exploring the roots of a concurrent resolution mechanism, this part looks into the little-known roots of the War Powers Resolution. This takes us back to World War II and later conflicts, including the Vietnam War. Then this part looks at the efforts to invoke the War Powers Resolution in 1999, during the start of the Kosovo-related NATO bombing campaign against Serbia, and in 2011, during the American participation in the NATO bombing of Libya. To put this in perspective, the section starts by suggesting why Chadha, although a decisive consideration in legislation delegating domestic administrative authority, is not so in war powers.

80. Tiefer, Appropriation Riders - Iraq, supra note 25, at 320-321.

81. Yoo, supra note 16 , at 367.

82. There were no United Nations forces in Libya, but there was a Security Council resolution, unlike Kosovo in 1999, which Russia vigorously opposed. See S.C. Res. 1973, U.N. Doc. S/RES/1973 (Mar. 17, 2011) (authorizing no-fly zone over Libya). 


\section{A. Functionalism and Formalism; Chadha Revisited}

The functional arrangement of shared war powers means was most eloquently expounded by the greatest functionalist opinion on the subject, Justice Jackson's concurrence in Youngstown Sheet \& Tube Co. v. Sawyer. His concurring opinion subsequently received authoritative acceptance from the Supreme Court as a whole in Dames \& Moore v. Regan. ${ }^{84}$

Justice Jackson's opinion in Youngstown separated war actions that the President might propose into three categories: those clearly authorized by a law enacted by Congress, those clearly against such a Congressional enactment, and a middle category, the "zone of twilight:",85

When the President acts in absence of either a congressional grant or denial of authority ... there is a zone of twilight in which he and Congress may have concurrent authority, or in which its distribution is uncertain. Therefore, congressional inertia, indifference or quiescence may sometimes, at least as a practical matter, enable, if not invite, measures on independent presidential responsibility. In this area, any actual test of power is likely to depend on the imperatives of events and contemporary imponderables rather than on abstract theories of law. ${ }^{86}$

Justice Jackson captures several functionalist themes about the nature of war powers in the "zone of twilight." His opinion identifies the war powers as an issue "in which [the President] and Congress may have concurrent authority." ${ }^{87}$ Moreover, Justice Jackson comments that legal conclusions about war powers exercised in this zone turn on "the imperatives of events and contemporary imponderables." This Jacksonian approach did not use "contemporary factors" to dispense with what Congress had decided, but rather, its "three zones" analysis turned precisely upon what Congress had done and not done. ${ }^{88}$ Moreover, the approaches of

83. The Court (speaking through Justice Black) found that President Truman did not have authority, during the Korean War, to seize the nation's steel mills in order to end a labor conflict. Youngstown, 343 U.S. 579, 587-589; id. at 655 (Jackson, J., concurring).

84. Dames \& Moore, 453 U.S. 654, 668-669 (1981).

85. Youngstown, 343 U.S. at 635-638 (Jackson, J., concurring). Dames \& Moore restated the same concept by saying that most executive actions fall "along a spectrum running from explicit congressional authorization to explicit congressional prohibition." 453 U.S. at 669 .

86. Youngstown, 343 U.S. at 637 (Jackson, J., concurring).

87. Id. at 642-644. The image of a "zone of twilight" itself betokens transition between day and night, shading between light and dark, or, in other words, an area of inbetween-ness rather than a sharp division.

88. Justice Jackson's description of "congressional inertia, indifference or quiescence" reflects that Congress might have neither expressly authorized, nor expressly prohibited, a proposed action. Also, the Justices found there is still much to be learned from the exact record of congressional action, as Justices Jackson and Frankfurter examined concretely in 
Justices Jackson and Frankfurter analyzed the nuances of a background consisting of a mixture: statutes with a pure delegation of authority; statutes with a delegation of authority subject to a legislative veto; and actions by Congress such as hearings. ${ }^{89}$

Viewing Youngstown as a war powers decision invites consideration of the constitutionality of bicameral resolutions in war powers. Some may take it for granted that Justice Jackson could not be talking about how Congress acted - i.e., by bicameral resolution rather than by legislation signed by the President - but only the subject on which Congress acted or did not act - i.e., seizure of factories to end strikes. However, in context, Justice Jackson left this unclear. As discussed below, Justice Jackson's period in national legal affairs had been one of extraordinary fluidity and experimentalism in war powers before and during World War II, including the use of legislative veto mechanisms. The legislative background on factory seizures in World War II that received much focus in Youngstown included actions by one or both chambers of Congress not to move bills on the subject. ${ }^{90}$ While there are ways to frame such inaction within tight formalist perspectives, Justices Jackson and Frankfurter may have approached them more simply and naturally through their own functionalist perspective. They may have simply considered that inaction by one or both chambers of Congress was, in general, rather than in the interpretation of the meaning of a law, a relevant factor to consider, from a functionalist perspective, in the twilight zone of war powers.

that case. See id. at 638-639 (Jackson, J., concurring); id. at 599-602 (Frankfurter, J., concurring).

89. There are two tabular appendices of relevance in Justice Frankfurter's opinion: one is "Synoptic Analysis of Legislation Authorizing Seizure of Industrial Property," 343 U.S. at 615-620, the other is "Summary of Seizures of Industrial Plants and Facilities by the President." Id. at 620-628. These include both statutes with a sharply limited (i.e., not approving the steel seizure) but pure delegation of authority, and the World War II statutes with a delegations of authority that are not pure delegations but are subject to a legislative veto. Discussion of these World War II statutes with legislative vetoes (listed in the Youngstown Appendices I and II) can be found in the Opinion of Justice White in Chadha, see infra note 95 . For discussion of congressional hearings, see Youngstown, 343 U.S. at 607-608 (Frankfurter, J., concurring).

Consider the result if the record in Youngstown had consisted of a murkier interplay of statutory provisions and executive claims, with Congress much less definitively rejecting the power of seizure, but with as much or more significant legislative veto provisions and congressional steps such as hearings. This would have moved the analysis away from Justice Jackson's third zone, but still far from the first. In other words, the situation would have been in the second zone at its "border" near the third zone - the zone of concurrent powers, with Congress using legislative veto provisions and with votes by one chamber signaling some degree of congressional assertion of authority but not as absolute as a set of enactments purely rejecting the Executive action.

90. See Youngstown, 343 U.S. at 585-586 (majority opinion); id. at 639 (Jackson, J., concurring); id. at 599 n.2, 600-602, app. 615-629 (Frankfurter, J., concurring). 
Against such fundamental Supreme Court decisions is the opinion firmly in opposition to legislative veto mechanisms, INS v. Chadha. ${ }^{91}$ Chadha invalidated a legislative veto in the immigration laws, a statutory provision by which Congress had delegated the Attorney General the power to cancel administrative stays of deportation for certain aliens, but each House of Congress could veto such stays. ${ }^{92}$ Chief Justice Burger's opinion applied to the realm of domestic delegations of power by legislation. The question is whether this applies to war powers, where there might be interaction by which Congress affected what the President does, not as a matter of domestic delegation, but as to more fluid, concurrent powers.

This article accords Chadha much less control over war powers, using the author's particular experience. In the Supreme Court in Chadha, the decisive briefing occurred between the Justice Department, on one side, challenging the constitutionality of the provision in that case, and the United States Senate, providing the official defense on the other side. The author, in the Senate Legal Counsel's office wrote the draft of the key brief on the merits. Thirty pages of that Senate brief analyzed and systematized many scores of enacted legislative veto mechanisms, based on the author's review not merely of the statutes, but of their individual, extensive legislative histories in their individual, complex historical context. ${ }^{93}$ The indication that this briefing mattered more than most was that whole sections of the brief were lifted to form pieces of the monumental dissent by Justice White. ${ }^{94}$ And, nothing in the brief or the opinion by Justice White mattered more than the section on legislative vetoes in war powers.

Part of the brief concerned the run-up to the War Powers Resolution's bicameral resolution mechanism. ${ }^{95}$ The run-up had come through the Korean War, the Middle East Crisis of 1957, and the Tonkin Gulf Resolution in the Vietnam War. The details of this are below. What matters is that the brief put the War Powers Resolution's mechanism and its background before the Court.

Two opinions apart from Chief Justice Burger's recognized the relevance of war powers and respected it. Justice Powell's concurrence struck the immigration mechanism but expressly shied away from the concurrent resolution mechanism in the War Powers Resolution. ${ }^{96}$

91. Chadha, 462 U.S. at 919.

92. Id. at 957-959.

93. Supplemental Brief on Reargument of the United States Senate, ApelleePetitioner, Chadha, 462 U.S. 919 (Nos. 80-1832, 80-2170, 80-2171), 1982 U.S. S. Ct. Briefs LEXIS 1636 [hereinafter Senate Chadha brief]. The author is named on the brief, and was the chief drafter of the sections in question, under the invaluable supervision of the Senate Legal Counsel, Michael Davidson, and the Deputy Senate Legal Counsel, M. Elizabeth Culbreth, and with the help of the current Senate Legal Counsel, Morgan J. Frankel.

94. See Chadha, 462 U.S. at 1003 (White, J., dissenting), app. 1 1003-1013.

95. Senate Chadha brief, supra note 93 , at $* 31-* 39$.

96. "The legislative veto has been included in a wide variety of statutes, ranging from 
Justice White laid out an appendix of "Statutes with Provisions Authorizing Congressional Review, consisting of "fifty-six statutes . . . divided into six broad categories" ${ }^{\text {"97 }}$ of which the first category was "foreign affairs and national security." The second such provision in that category was analyzed thus:

War Powers Resolution ... Absent declaration of war, President may be directed by concurrent resolution to remove United States armed forces engaged in foreign hostilities. ${ }^{98}$

In the text of the opinion, Justice White further explicated why he thought that mechanism crucial:

During the 1970's the legislative veto was important in resolving a series of major constitutional disputes between the President and Congress over claims of the President to broad impoundment, war, and national emergency powers. The key provision of the War Powers Resolution, 50 U.S.C. $\$ 1544(\mathrm{c})$, authorizes the termination by concurrent resolution of the use of armed forces in hostilities. ${ }^{99}$

In light of the pressure from two sides, the Senate advocates, and more importantly the concurring and dissenting Justices, especially Justice White, Chief Justice Burger shied away from the War Powers Resolution. In many respects, there is one enormous footnote of his opinion in which he gives as much of an answer as anywhere to those respectful of the War Powers Resolution. ${ }^{100} \mathrm{He}$ describes the veto repeatedly as inappropriate or unnecessary where Congress has delegated to the executive the power it exercises, by legislation, signed by the President and confined by the domestic non-delegation doctrine. ${ }^{101}$ That is, of course, what Congress had done in Chadha itself, in which it delegated power to the Attorney General

bills for executive reorganization to the War Powers Resolution. Whether the veto complies with the Presentment Clauses may well turn on the particular context in which it is exercised, and I would be hesitant to conclude that every veto is unconstitutional on the basis of the unusual example presented by this litigation." Chadha, 462 U.S. at $960 \mathrm{n} .1$ (Powell, J., concurring in judgment) (internal citations omitted). Justice Powell's holding that the mechanism in Chadha was unconstitutional was based on his conclusion that Congress had "assumed a judicial function in violation of the principle of separation of powers." Id. at 960.

97. Id. at 1003-1013 (White, J. dissenting) app. 1.

98. Id. at 1003 (internal citations omitted).

99. Id. at $970-971$.

100. Id. at 953 n.16 (majority opinion).

101. Id. at $953 \mathrm{n} .16,954-955$. The non-delegation doctrine does not apply in foreign relations the way it applies domestically. United States v. Curtiss-Wright Export Corp., 299 U.S. 304, 315-324 (1936). The Supreme Court strongly reconfirmed this distinction in 1998. Clinton v. City of New York, 524 U.S. 417, 444-446 (1998). See Charles Tiefer, Congress in a Straitjacket?, LEGAL TIMES OF WASH., June 29, 1998, at 23, 24-25. 
by legislation, signed by the President and confined by the domestic nondelegation doctrine.

However, war powers do not work the way the legislation that Chief Justice Burger discusses works. Congress did not enact a "War Law" pursuant to which the President periodically goes to war. Congress's share of war powers, and the President's share of war powers, are concurrent powers coming from diverse provisions of the Constitution, not from the simple uniform vehicle of delegation. Piecing together the validity of an exercise of war powers is not at all like piecing together what Chief Justice Burger said about domestic delegating legislation and the non-delegation doctrine. ${ }^{102}$ Chief Justice Burger concludes: "Congress's authority to delegate portions of its power to administrative agencies provides no support for the argument that Congress can constitutionally control administration of the laws by way of a [c] ongressional veto., 103

This is not to say that Chief Justice Burger expressly separated the concurrent resolution in war powers from what he was discussing. It is merely to say that he focused on the non-war-powers context of delegating legislation in which his reasoning had its strongest support. He did not go anywhere near an explicit contest with either the Senate or, more important, Justice White, about concurrent war powers. It is worth looking at why war powers may be, and in fact are, a special context and subject, keeping Chadha in mind but not thinking that the subject is foreclosed by an opinion which very visibly declined to mention it or to reason about it.

\section{B. War Powers Resolution Section 5(c): Background ${ }^{104}$}

The War Powers Resolution has several very important sections. Most attention goes to a provision not relevant here, the provision that limits how long a President may continue hostilities without congressional authorization. ${ }^{105}$ This discussion focuses on the provision, Section 5(c), that created a concurrent resolution mechanism by which Congress, by a vote of the House and Senate (not presented to the President), may terminate American involvement in hostilities. ${ }^{106}$

102. See Chadha, 462 U.S. at 953 n.16. The footnote cites both Supreme Court and classic D.C. Circuit precedents, as well as commentary, all on the non-delegation doctrine.

103. Id.

104. Section 5(c) has drawn extensive commentary. Most commentators have distinguished $\$ 5(\mathrm{c})$ from Chadha. However, the debate has been sprawling and loose enough that some who take it as unconstitutional appear quite unaware that others do not. The provision receives useful illuminations from study of its little-known yet striking background in thirty years of similar prior provisions.

105. See 50 U.S.C. $\$ 1544$ (b) (2006).

106. The provision is referred to as "Section 5(c)" because in the War Powers Resolution itself, Pub. L. No. 93-148, (1973), the provision is found in Section 5(c). It is codified at 50 U.S.C. §1544(c). 
In considering the War Powers Resolution, Congress expressly considered the constitutionality of the provision that became Section 5(c). The House bill had a provision for termination of conflicts by concurrent resolution; ${ }^{107}$ the Senate bill did not. ${ }^{108}$ The final version, in effect today, states: $:^{109}$

(c) Concurrent resolution for removal by President of United States Armed Forces

Notwithstanding subsection (b) of this section, at any time that United States Armed Forces are engaged in hostilities outside the territory of the United States, its possessions and territories without a declaration of war or specific statutory authorization, such forces shall be removed by the President if the Congress so directs by concurrent resolution.

Justice White's dissenting opinion in Chadha discussed Section 5(c)'s roots in Congress's conditioning grants of power during World War II:

World War II occasioned the need to transfer greater authority to the President in these areas. [With a legislative veto,] Congress could confer additional authority while preserving its own constitutional role. During World War II, Congress enacted over thirty statutes conferring powers on the executive with legislative veto provisions. President Roosevelt accepted the veto as the necessary price for obtaining exceptional authority. ${ }^{110}$

After World War II, provisions with similar mechanisms ${ }^{111}$ served crucial roles in legislation addressing the Truman Doctrine, the Korean War, the Middle East Crisis of 1957, and the Vietnam War. ${ }^{112}$ For example, the original Tonkin Gulf Resolution, the authorization President Johnson obtained from Congress for the Vietnam War, had in it one of these provisions:

This resolution shall expire when the President shall determine that the peace and security of the area is reasonably assured by international conditions created by action of the United Nations or

107. H.R. REP. No. 93-287, at 2355 (1973).

108. On the basis of an opinion of constitutionality from Professor Paul A. Freund, one of the leading scholars on this subject, the conference committee and the two chambers adopted the concurrent resolution mechanism. See H.R. CONF. REP. 93-547, at 2365 (1973).

109. 50 U.S.C. $\$ 1544(\mathrm{c})$.

110. Chadha, 462 U.S. at 969 (White, J., dissenting) (footnotes omitted).

111. Bracknell, supra note 38 , at $208 \mathrm{n} .112$.

112. Senate Chadha brief, supra note 93 , at *37, *37 n. 44 . 
otherwise, except that it may be terminated earlier by concurrent resolution of the Congress. ${ }^{113}$

Justice White sums up well when he says "Congress could confer additional authority while preserving its own constitutional role," and "[the President] accepted the [legislative] veto as the necessary price for obtaining exceptional authority." 14

Usefully, Justice White's comments distinguish the concurrent resolution mechanisms in the Middle East crisis of 1957 and the Vietnam War from the many "legislative veto" provisions regarding domestic regulatory and energy actions. War powers are shared by the President and Congress, not separated like the powers of enactment (Congress) and delegated administration (executive). A mechanism like the one in the Tonkin Gulf Resolution or the War Powers Resolution has nothing to do with the delegations in laws like regulatory or criminal provisions. Rather, it provides a flexible way Congress and the President share their concurrent war powers.

Chadha had a radical impact on the diverse legislative veto mechanisms, but the impact varied in different areas. The enactment of legislative vetoes fell off in the areas of regulatory rulemaking. However, Louis Fisher, scholar at the Library of Congress, has counted many legislative veto-like mechanisms, described this way in the broadest sense, still on the books or newly enacted since Chadha. ${ }^{115}$ An important example is that Congress continues to allow agencies to shift appropriations from one purpose to another by procedures of reprogramming and the like. It is notable that much of this is remote from regulatory rulemaking or other court-supervised delegated authority. These involve a substantial involvement of congressional appropriations committees in deciding whether they favor the reprogramming.

Congress continues mechanisms of diverse kinds in war powers that dovetail with the discussion about the Boland Amendments. As Fisher notes:

Another type of informal arrangement is reflected in the "Baker Accord" of 1989. In the early months of the [George H. W. Bush] Administration, Secretary of State James A. Baker III decided to give four committees of Congress a veto power over the fractious issue of funding the Nicaraguan Contras. ... In return for receiving

113. Pub. L. No. 88-408, $\$ 3,78$ Stat. 384, (1964) [hereinafter Tonkin Gulf Resolution]. The Tonkin Gulf Resolution was repealed by statute. By this time, President Nixon asserted powers that the repeal did not affect, such as approval of the war by voting its appropriations, and his own powers as Commander in Chief.

114. Chadha, 462 U.S. at 969 (White, J., dissenting) (footnotes omitted).

115. Louis Fisher, Committee Controls of Agency Decisions (Cong. Res. Service RL33151), Nov. 16, 2005. 
$\$ 50$ million in humanitarian aid for the Contras, Baker reportedly agreed that a portion of the funds could be released only with the approval of certain committees and party leaders. ${ }^{116}$

Fisher traces how Congress considered repealing the concurrent resolution mechanism of Section 5(c), but instead merely supplemented it, without a repeal, by a separate provision for a joint resolution. ${ }^{117}$

\section{Kosovo, Iraq, and Libya}

\section{Kosovo}

Beside the brief Persian Gulf War, the United States committed its armed forces into one major substantial conflict between the War Powers Resolution of 1974 and September 11, 2001. Namely, in 1995 the United States sent ground forces to keep peace in Bosnia, and then, more important, in 2000 engaged in a massive bombing campaign against Serbia to force an end to Serbia's actions against Kosovo. That makes this conflict the best to see the use of Section 5(c).

To give an account in abbreviated chronology, in late 1995 President Clinton sought congressional support for a Bosnia deployment. He dropped his objection to $\$ 7$ billion Congress wanted for defense beyond the budget, and the defense appropriation he needed for the deployment became law. Separately, after major debates on the commitment, the Senate voted support for the deployment. A strong majority of House Republicans opposed the deployment. Yet, at the key point, the House defeated a provision prohibiting funds for the deployment, by the close vote of 210 218. Thus, although the votes of the Senate and House had not occurred by affirmation of a single vehicle as sought by Chadha, the President could, and did, take the votes in the realm of shared real war powers as support for the deployment.

116. Id. at 23-24.

117. "After Chadha, some Members of Congress introduced legislation to change the War Powers Resolution, which contains a provision that allows Congress to pass a concurrent resolution to order the President to withdraw troops engaged in combat. These lawmakers suggested that the concurrent resolution be replaced by a joint resolution of disapproval. As finally enacted, however, the procedure for a joint resolution was not added to the War Powers Resolution. It became a freestanding legislative procedure that is available to force a vote to order the withdrawal of troops." Louis Fisher, Legislative Vetoes after Chadha (Cong. Res. Service RS22132), May 2, 2005, at 2 (internal citations omitted). See also 50 U.S.C. \$1546(a) (the "freestanding legislative procedure allowing a vote on withdrawal of troops"). The Fisher memo does distinguish between committee-level veto mechanisms, which have continued, and those at the level of one- and two-chamber action (i.e., concurrent resolution mechanisms), which have not. 
The Kosovo activity mattered even more, as the United States employed a massive and economically devastating bombing campaign very much a war. Early on, the Senate passed a resolution stating that the President was authorized to conduct air strikes in the region. The House voted against American combat "ground elements," although none were contemplated. Most interestingly, the House considered a resolution expressly pursuant to Section 5(c) to withdraw all armed forces from the operations, ${ }^{118}$ but voted it down. ${ }^{119}$

A reader could review this record and see only that the chambers had acted inconsistently, or had not followed the WPR provision for a Congressional concurrent resolution for withdrawal from hostilities, or the President had not shown clear submission to the WPR requirement to withdraw from hostilities when Congress so orders. Those who can think functionally about the point of a congressional role do not lose faith at the messiness of the operation in action. There is little reason to think that the House of Commons under the Stuart monarchs, or the colonial legislatures under English governors, acted strictly according to formalists' rules, either. A shared power means the political branches may work matters out by rough-hewn methods. ${ }^{120}$

The votes in Congress about whether to authorize commitments to hostilities in Kosovo showed that the Congress had debated the issue and paid it much attention. Had the House and Senate possessed a determination to block the war action, they had the opportunities to do so. Particularly, the House's opportunity did not come from general legislation or general appropriation channels, but specifically from Section 5(c). This provides all the more reason to consider such a mechanism to be a legitimate part of the sharing of war powers.

\section{Iraq Votes}

The congressional votes with respect to Iraq do not present the same picture as the Kosovo and Libya matters. These Iraq votes took place specifically in the context of enacting defense spending bills, rather than as separate expressions of congressional positions as in Kosovo and Libya.

118. Removal of United States Armed Forces from the Federal Republic of Yugoslavia, H.R. Con. Res. 82, 106th Cong. (1999).

119. See, e.g., Gerald G. Howard, Combat in Kosovo: Ignoring the War Powers Resolution, 38 Hous. L. REV 261, 285-287 (2001); Jonathan F. Mitchell, Legislating ClearStatement Regimes in National-Security Law, 43 GA. L. REv. 1059, 1078-1079 (2009); Michael Mandel, Note, A License To Kill: America's Balance of War Powers and the Flaws of the War Powers Resolution, 7 CARDOZo PuB. L. POL'Y \& ETHICS J. 785, 802-803 (2009).

120. Cf. 145 Cong. ReC. H2456-03 (1999) (statement of Rep. David Obey) ("Over the last month this Congress could not have been more irresponsible in the way it has dealt with the issue in Kosovo if it had taken lessons... Never, never in the 30 years that I have served here have I seen less vision. Never have I seen less leadership. Never have I seen more confusion."). 
Nevertheless, they deserve attention, as significant congressional action with respect to the other long war, besides Afghanistan, since 9/11 - the Iraq war.

In the 2006 congressional elections, control of both the House and Senate shifted from Republican to Democratic, attributed among other reasons to disaffection with the Iraq war. Yet in January 2007, President Bush announced a military buildup in Iraq of 20,000 additional ground troops, known as "the surge." Congressional leaders announced they would seek a funding bill with a withdrawal schedule; President Bush said he would veto any bill with a timetable for withdrawal. As a commentator put it, "[ $t]$ his set the stage for a constitutional confrontation of the highest magnitude." 21 On April 25, the House passed an appropriations bill with a timetable for withdrawal and the next day the Senate passed the same bill. ${ }^{122}$ On May 1, President Bush vetoed it, and an override attempt failed. ${ }^{123}$ Congress passed, and the President signed, an appropriations bill a month later, ${ }^{124}$ which required independent assessments of the Iraqi government and military forces. Some described the new benchmarks as token restrictions, while others said a serious review of the war could be forced that way. ${ }^{125}$

One straightforward reading of the Iraq votes is that they provide no support for the legitimacy of a concurrent resolution mechanism. Congress in 2007 had the votes for a concurrent resolution, but it instead put its faith into moving a withdrawal schedule as an appropriation condition. When President Bush vetoed this, he showed that the House and Senate could not succeed on their own in forcing a President to change his war effort.

The 2007 situation was not a typical or universal one. Congress had authorized the Iraq War in 2002. ${ }^{126}$ It may be noted that Section 5(c) of the War Powers Resolution only provides for termination of hostilities by concurrent resolution when Congress has not authorized them. ${ }^{127}$ There

121. David L. Larson, The Constitution and U.S. Foreign Policy: The President, the Congress, and the People, 32 FleTCHER F. WORLD. AFF. 143, 152-154 (2008). This section on Iraq draws considerably on this piece.

122. Carl Hulse, Senate Passes Bill Seeking Iraq Exit; Veto is Expected, N.Y. TIMES, Apr. 27, 2007, at A1; Carl Hulse \& Jeff Zeleny, House Approves War Spending Measure that Requires U.S. To Start Pullout from Iraq, N.Y. Times, Apr. 26, 2007, at A12.

123. Sheryl Gay Stolberg \& Jeff Zeleny, Bush Vetoes Bill Tying Iraq Funds to Exit Schedule, N.Y. Times, May 2, 2007, at A1; Edward Wong \& Sheryl Gay Stolberg, A Draft Oil Bill Stirs Opposition from Iraqi Blocs, N.Y. TimEs, May 3, 2007, at A1.

124. U.S. Troop Readiness, Veterans' Care, Katrina Recovery, and Iraq Accountability Appropriations Act, Pub. L. No. 110-28, 121 Stat. 112 (2007).

125. Carl Hulse, Congress Passes War Funds Bill, Ending Impasse, N.Y. TIMES, May 25,2007 , at $\mathrm{A} 1$.

126. Authorization for Use of Military Force against Iraq, Pub. L. No. 107-243, 116 Stat. 1498 (2002) [hereinafter Iraq Resolution].

127. See 50 U.S.C. $\S 1544(c)$. 
may be more room for congressional-presidential interplay in a conflict that Congress never authorized.

Second, President Bush was dead-set on continuing the Iraq War without withdrawal, putting this above all other considerations. He would not accept any congressional communication short of an appropriation law, passed over his veto, cutting off the money for the war, and it is by no means clear what he would have done in the face even of such a cut-off. Not all Presidents approach all issues of war powers in such an absolutist way. As seen above in Kosovo, and in the next section about Libya, a dialogue may occur in which the Congress's priority is to avoid commitments of ground troops while the President's priority is to conduct an air operation. Congress receives more respect for its role in war powers - such as its actions in enacting and in employing a concurrent resolution mechanism - from a President who has flexibility in his plans.

\section{Libya}

Looking back at the successful ousting of Muammar Gadhafi in 2011, history may well play down the contemporary controversial nature of American military involvement. As part of a NATO operation with the stated goal of protecting Libyan civilians, the American military launched a series of sixty or so missile strikes against the Gadhafi regime. There was little danger of American casualties, but the strikes had strategic significance because of the superior American military capability to suppress Libyan air defenses and thereby make way for the rest of NATO's air operations.

President Obama approved the operation without consultation with Congress - it was in recess and he was on a mission in Brazil. This produced one prominent legal controversy not relevant to this article - the legal view put forth by the State Department Legal Adviser, Harold H. Koh, ${ }^{128}$ that the operation did not constitute "hostilities" subject to the War Powers Resolution's ninety-day clock. ${ }^{129}$ A different controversy does relate to this article. Congress did have votes with respect to U.S. military operations in Libya. On June 24, 2011, the House rejected, 123-295, a resolution to support the mission. ${ }^{130}$ However, the House also defeated, $180-238$, a bill to prohibit money for activities such as missile strikes. ${ }^{131}$

128. Libya and War Powers: Hearing Before the S. Comm. on Foreign Relations (June 28, 2011) (testimony of Harold Koh), available at http://www.foreign.senate.gov/ imo/media/doc/Koh_Testimony.pdf.

129. For background on this issue, see WHITE HOUSE REPORT, UNITED STATES ACTIVITIES IN LiBYA (June 15, 2011), available at http://www.washingtonpost.com/wpsrv/politics/documents/united-states-activities-libya.html.

130. H.R.J. Res. 68, 112th Cong. (2011).

131. H.R. 2278, 112th Cong. (2011); Jennifer Steinhauer, House Rebuffs Libya Mission; No Funds Cut, N.Y. TIMES, June 25, 2011, at A1. 
Later, on July 7, the House turned back, 199-229, an amendment that would prohibit funds for the U.S. military operation in Libya. ${ }^{132}$ However, the House did adopt, 225-201, an amendment to bar funding for training or equipping the Libyan opposition. ${ }^{133}$

Observers recognized that the 2011 Libya pattern resembled the 1999 Kosovo pattern. As Congressional Quarterly observed in 2011, "Congress witnessed [this] sort of heated debate in 1999, when [President] Clinton notified but did not seek authorization from Congress about his order for U.S. military participation in NATO airstrikes in Kosovo to prevent ethnic cleansing. "That move set off a flurry of votes on measures both backing and opposing the engagement." ${ }^{134}$

As at other tests of authorization of military action, it could be urged to blow off these steps - or decisions not to take steps - by one or both chambers of Congress as without significance for constitutional war powers. On this way of thinking, the President decided what to do, and absent something like an enactment, or an appropriation condition about hostilities, Congress could not and did not take any step with effect upon his war powers. However, there is a better way of looking at it: the congressional votes marked off an area within which the President might have discretion, while making his position shaky if he strayed far beyond that area. Congress's signals could be read as saying something like: President Obama could have his initial series of missile strikes, but he was well-advised after that to turn the leadership over to other NATO nations, even for air operations. Moreover, he should not participate in any NATO effort to provide training or equipping of Libyan opposition forces, regardless of any humanitarian objectives.

\section{Ways of Understanding Congressional Mechanisms}

On one level, it suffices to show the history of concurrent resolution mechanisms leading up to Section 5(c) of the War Powers Resolution; that Chadha dealt with strict domestic delegations of administrative authority and not something as flexible as the concurrent war powers of the Congress and the President; and, the record of actions by one or both chambers (without full legislation signed by the President) such as with Kosovo and Libya. Still, on another level, the subject calls for setting forth an

132. H.R. Amdt. 543, 112th Cong. (2011).

133. H.R. Amdt. 542, 112th Cong. (2011); Alexander C. Hart \& Emily Cadei, With Pro-Obama Libya Measure on Hold in Senate, House Weighs In, CONG. Q. WKLY., July 9, 2011, 2011 WLNR 14228696.

134. Emily Cadei, As Libya Rebellion Stalls, Congress Mulls Its Role, CONG. Q. WKLY., April 23, 2011, 2011 WLNR 8429195. 
alternative conceptual understanding about why such a mechanism has legitimacy.

It was notable that situations as remote in time from each other as Kosovo in 1999 and Libya in 2011, with so much happening between them in terms of the long wars in Iraq and Afghanistan, had some similar lessons about the congressional role in war powers. It was a pattern in which the process of congressional votes was not the adoption of legislation with prohibitions, or appropriations conditions. Rather, activity by one or both chambers of Congress had significance, quite properly, because that allowed more democratic legitimacy into war powers.

The challenge was to find conceptual ways to understand how congressional votes might have legitimate war powers significance, say, as the way Congress might allow a drawdown in Afghanistan subject to a bicameral resolution to stop the drawdown if the situation seemed to require this.

One way consists of the impact of Congressional decision-voting on Presidential position-taking. Very simply, when the President pledges that he will abide by a decision of the House and Senate, he agrees to share war powers. A formalist would argue that this is just politics, like any other way to accord the House and Senate a role. Yet, the context for this is not like the context of a presidential pledge to an interest group. It has more than political significance because the House and Senate are more than just political entities. The Constitution gives them a concurrent role in war powers, a role that is flexible, and a presidential pledge fits with that.

Dames \& Moore v. Regan, the more recent follow-on from Youngstown, illustrates this. As the Court explains:

[F]ailure of Congress specifically to delegate authority does not, especially in the areas of foreign policy and national security, imply congressional disapproval of action taken by the Executive. On the contrary, the enactment of legislation closely related to the question of the President's authority in a particular case which evinces legislative intent to accord the President broad discretion may be considered to invite measures on independent presidential responsibility. ${ }^{135}$

Congressional inaction results from what one or both Houses do, without presidential signature or enactment, in contrast to putting in the Statutes at Large a new appropriation law or other legislation. A focus on congressional inaction in wartime has figured prominently in the Supreme

135. Dames \& Moore, 453 U.S. at 678 (internal citations and quotation marks omitted); see also Harold Hongju Koh, Why the President (Almost) Always Wins in Foreign Affairs: Lessons of the Iran-Contra Affair, 97 Y ALE L.J. 1255, 1306 (1988) (arguing that after Dames \& Moore, "a court may construe congressional inaction or legislation in a related area as implicit approval for a challenged executive action" (emphasis added)). 
Court decisions of the past decade on war-related issues. As Professor Howell has noted, "the Justices [have] made much of the fact that the President lack legislative authorization for his wartime directive [as in $E x$ parte Milligan] or that he acted contrary to the will of Congress (Youngstown)." ${ }^{136}$ So Dames \& Moore provides a way of conceptualizing a role in issues of authorizing presidential war powers of what one or both chambers do, even without legislation as action or inaction affecting presidential authority.

A second way is that both the Congress and the President could look at a concurrent resolution as the ultimate of all harbingers of a next step soon by appropriations. In other words, the President could view a concurrent resolution to stop a drawdown as a harbinger which the next appropriation law would follow by a condition stopping funds for the drawdown. To take a specific example, as to the Bosnia commitment in 1994, the steps by Congress in December 1995 arguably had legal significance. The steps occurred against the background that President Clinton could have, or not have, good-faith expectations about provisions in the next supplemental appropriations law. ${ }^{137}$

If the House and Senate had voted against the Bosnia commitment, even though they did not enact a prohibition by a bill sent to the President for signature, he could not gone ahead with a good-faith expectation of a favorable next step in the next supplemental. ${ }^{138}$ Because the Senate and House voted favorably to him, he could, and did, go ahead. The machinery of defense appropriations proceeds very much on the expectation of imminent congressional enactments of funding laws that could be affirmative about the next steps. ${ }^{139}$

136. William G. Howell, Wartime Judgments of Presidential Power: Striking Down But Not Back, 93 MinN. L. REv. 1778, 1811 (2009) (footnotes omitted); see Ex parte Milligan, 71 U.S. (4 Wall.) 2, 121 (1866) (noting lack of congressional authorization for military commissions to try civilians during the Civil War); but see Boumediene, 553 U.S. at 739, 792 (2008) (holding that military commissions, despite explicit congressional authorization, effected unconstitutional suspension of habeas corpus).

137. Cf. Orlando v. Laird, 443 F.2d 1039, 1042 (2d Cir. 1971).

138. For example, the appropriations for 1984 limited aid to the Contras to a low rate, which "would require the Administration to soon ask Congress for more, thus keeping the Administration's policy on a very short leash." Hayes, supra note 74 , at 1567 . From Congress's condemnatory reaction after public disclosure of the mining of the Nicaraguan harbors, id. at 1567-1568, it was obvious that the Administration could not have any goodfaith belief thereafter that Congress would ratify its drawing upon funds when the 1984 limit was reached. That funding shortage led to the search for alternative funding sources that became the Iran-Contra affair.

139. This theory explains that under some circumstances Presidents can legitimately take military actions not previously authorized by Congress, in the good-faith expectation that Congress will soon legislatively approve the action retroactively. In fact, there are powerful examples of the confirmation theory in operation. Authorizing legislation, after the fact of war powers exercise, is well established in Supreme Court case law, and Congress's 
For another example, as noted, the House and Senate votes on Kosovo could be viewed, although not producing an enacted law, as marking that President Clinton could conduct air operations but not ground operations. The Office of Legal Counsel produced an important, but often overlooked, memorandum construing a 1999 supplemental appropriation as authorization for the Kosovo action. ${ }^{140}$ The opinion noted and respected the House vote against ground troops. It said: "In reaching this conclusion [about the authorization of air operations], we need not and do not decide that the appropriation authorized ... the introduction of United States Forces onto the ground in Serbia or Kosovo. Interpretation of [the supplemental appropriation] must take into account the House of Representatives' vote on April 28 to block funding for ground troops. . ",141

The nature of war powers presents a situational mix of authorizing and non-authorizing aspects. The Afghan war evolved greatly in the decade after 2001. It started as a war against an enemy sovereign. It might have ended soon with the thorough defeat of that enemy sovereign, especially with a replacement government. But that insurgency, being too much neglected during the Bush administration, took deep root.

As presented in the early-to-mid 2010s, the war had entered its second decade, now cast as a long-term counterinsurgency. If the President sought, and the Congress supported, a drawdown but only with a concurrent resolution mechanism to stop it, they would use their shared war powers in a way the Framers would have approved. But the constitutional analysis about how Congress and the President might make such decisions cannot retreat, by formalist simplicity, from detailed analysis of such decisions. The mechanisms that the elected branches may establish for such decisions deserve scholarly acceptance.

\section{CONCLUSION}

Does this article point to yet another respect in which war powers law and national security law have entered a new situation since $9 / 11 ?^{142}$

Try this way of looking at it. From the War Powers Resolution, enacted in 1974, until 9/11, the United States had no long wars. It most certainly had very real wars. It had the Persian Gulf War, a very real war, in terms of casualties, stakes, cost, forces on each side, and so on. It had the

enactment of appropriations for the Vietnam War in the late 1960s and early 1970s, it has been argued, constituted confirmation for the expansion of that war. Orlando, 443 F.2d at 1042; Ely, supra note 34, at 27-30.

140. Authorization for Continuing Hostilities in Kosovo, Op. O.L.C., 2000 WL 33716980 (Dec. 19, 2000).

141. Id at *23. n.40.

142. For the kind of treatment suggested here, see Christopher A. Ford, War Powers As We Live Them: Congressional-Executive Bargaining Under the Shadow of the War Powers Resolution, 11 J.L. \& PoL. 609 (1995). 
bombing campaign in Kosovo, which certainly had, for the other side, casualties, and for our side, massive use of the air forces although without use of ground forces. Thus, the United States had real wars, but it did not have long wars, with both the Persian Gulf and Kosovo wars ending in a couple of months.

Hence, the landscape of war powers law in that period 1974-2001 kept at the forefront the kind of issues bequeathed by the Vietnam era, but not exactly the kind of issues that have arisen in the long wars of late. That 1974-2001 period started, following the Vietnam War, with a strong retrospective national look at how the war in Indochina had been so wrongly initiated. The War Powers Resolution came out of concern that another President would again make a unilateral war commitment like Vietnam, with Congress unable to deal itself in at the beginning. ${ }^{143}$

Then, starting with $9 / 11$, and joined soon by the Iraq war vote in 2002 and intervention in 2003, suddenly the United States had what turned out to be two wars - two bloody, costly ground wars. And, not just two wars, but two wars such as the United States had not conducted in 1974-2001: long wars. Some of the issues from 1974-2001 continue. Yet, in the past decade, war powers law and national security law have increasingly addressed the issues not found in those initial stages of wars or in short wars, as in the era of 1974-2001, but rather, these new issues as to the wars in Iraq and Afghanistan.

Issues have come to the fore about different kinds of congressional input over time; about whether drawdowns can be worked out between the branches; about congressional mechanisms for compromising with a President; and, so on. These are issues of long wars, and this is an article about long wars.

These kinds of issues suggest a need for suppleness, rather than reasoning built on old patterns or formal grounds. Flexible concerns suffuse the world of long wars.

Historical background always helps a great deal, as it has here. This article and the other two in the author's trilogy depend upon the rich vein of historical insight in the work of Professors Barron and Lederman, and Professors Lobel and Prakash.

Their history raises the right kinds of questions. Of course great Presidents facing great crises from Washington to Lincoln to Franklin Roosevelt acted flexibly, without taking their signals from some rigidlydefined-in-law office. However, the answers they worked out live on as

143. The biggest clash over war powers, combined with separation of powers, in the era of 1974-2001, may well have been the one about the Boland Amendments in the 1980s, precisely because it again seemed, as in Vietnam, that the President might make a unilateral war commitment (against Nicaragua) without a real congressional authorization at the beginning. 
precedents, to suggest and to illuminate. As for this article's discussion, it draws on how President Franklin Roosevelt went with dozens of postenactment mechanisms to get through World War II. Congress imposed one on President Nixon, in the War Powers Resolution, in reaction to the experience of presidential dragging-on of a long war.

Suppleness does not involve embracing every innovation that comes along. President George Bush ${ }^{144}$ wrote an unusual number of signing statements, and this innovation, by and large, received strong criticism from a constitutional perspective. Many other unilateral innovations also occurred, some unwelcome. ${ }^{145}$ The reader is merely invited to accept the invitation to think with suppleness of war powers in terms of the flexibility of the real world.

144. Most readers will assume this is a reference to President George W. Bush of 20012008. To be sure, it would be most true of him. However, it was also somewhat true of President George H.W. Bush of 1989-1992. Tiefer, supra note 74, at 31-60.

145. In 2002, President Bush went beyond merely declining to submit the Rome Treaty on the International Criminal Court to the Senate for its approval. He took an unprecedented step of "withdrawing" significance from the previous signature on it - a previous signature which did not approve it unless and until the Senate did so - a step dubbed by the press the "unsigning" of the instrument. 